\title{
Review article: Pathophysiological consequences of SARS CoV-2
}

\author{
Hadeel M. Hameed ${ }^{1}$, Hiyam N. Maty ${ }^{2}$, Fanar A. Isihak ${ }^{3^{*}}$ \\ ${ }^{1,2}$ Department of physiology, Biochemistry and pharmacology, College of Veterinary Medicine, University of \\ Mosul,Iraq \\ ${ }^{3}$ Department of Microbiology, College of Veterinary Medicine, University of Mosul, Mosul, Iraq \\ E-mail: ${ }^{1}$ hadeel.mohammad@uomosul.edu.iq, ${ }^{2}$ hyaimn.m@unmosul.edu.iq, ${ }^{3 *}$ fanar1976@uomosul.edu.iq
}

(Received July 10, 2020; Accepted August 25, 2020; Available online March 01, 2021)

DOI: $10.33899 /$ edusj.2020.127225.1089, (C) 2020, College of Education for Pure Science, University of Mosul.

This is an open access article under the CC BY 4.0 license (http://creativecommons.org/licenses/by/4.0/).

\begin{abstract}
Coronavirus outbreak occurred in late 2019 and called (COVID-19), caused by SARS-CoV-2 which firstly emerged in Wuhan city/China. This virus mostly attacks the respiratory system and therefore is more likely to destroy lung tissue and cause pneumonia; although lung is the target tissue but many organs of COVID 19 patients affect by virus invasion and showed numerous Physiological consequences. Angiotensin converting enzyme-2 (ACE2) receptors for the virus attachment are distributed in human's tissues including "lungs, heart, kidneys, intestines, brain and testes" that are recognized as a possible targets of COVID-19. The vital functions of these organs may impaired with different levels as a result of viral infection and replication. Patient with type A especially those formerly have been identified with cardiovascular diseases in particular increased blood pressure, are more expected to develop acute COVID-19 symptoms. Clot producing disorders with SARS CoV2 infected patients were observed firstly by researchers in China. Thus untreated patients revealed large arterial pulmonary clots can put permanent pressure on the heart, leading to cardiac attack. Anxiety about the coronavirus outbreak is extremely common. Therefore, some individual may showed a huge concern that can disturb their regular life. Stress and fear from infection can be devastating and cause powerful excitements in children and adults. Therefore this study aims to shed light on pathophysiological consequences and stressful conditions of COVID-19 in patients including many of boby organs and $\mathrm{ABO}$ system.
\end{abstract}

Keywords: SARS-CoV-2 , COVID-19, Stress , ACE2, Blood clot , ABO system

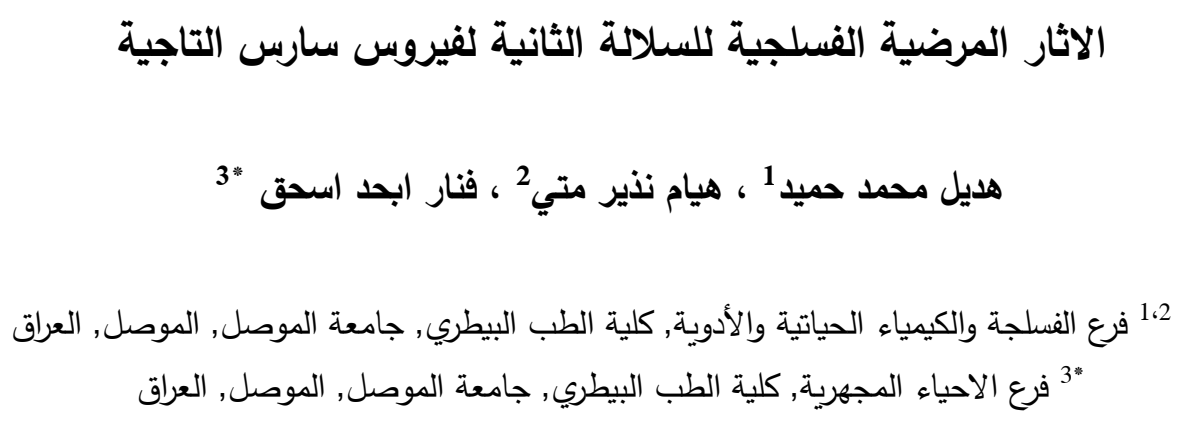

الخلاصة

لوحظ في نهاية عام 2019 تقشي وباء فيروس كورونا التاجي والمسمى ب (COVID-19) والذي يسببه فيروس-SARS.

Cقد حدث التفشي الأول بهذا الوباء في مدينة ووهان / الصين • حيث يهاجم هذا الفيروس في غالبا الجهاز التتفسي ، مؤديا 


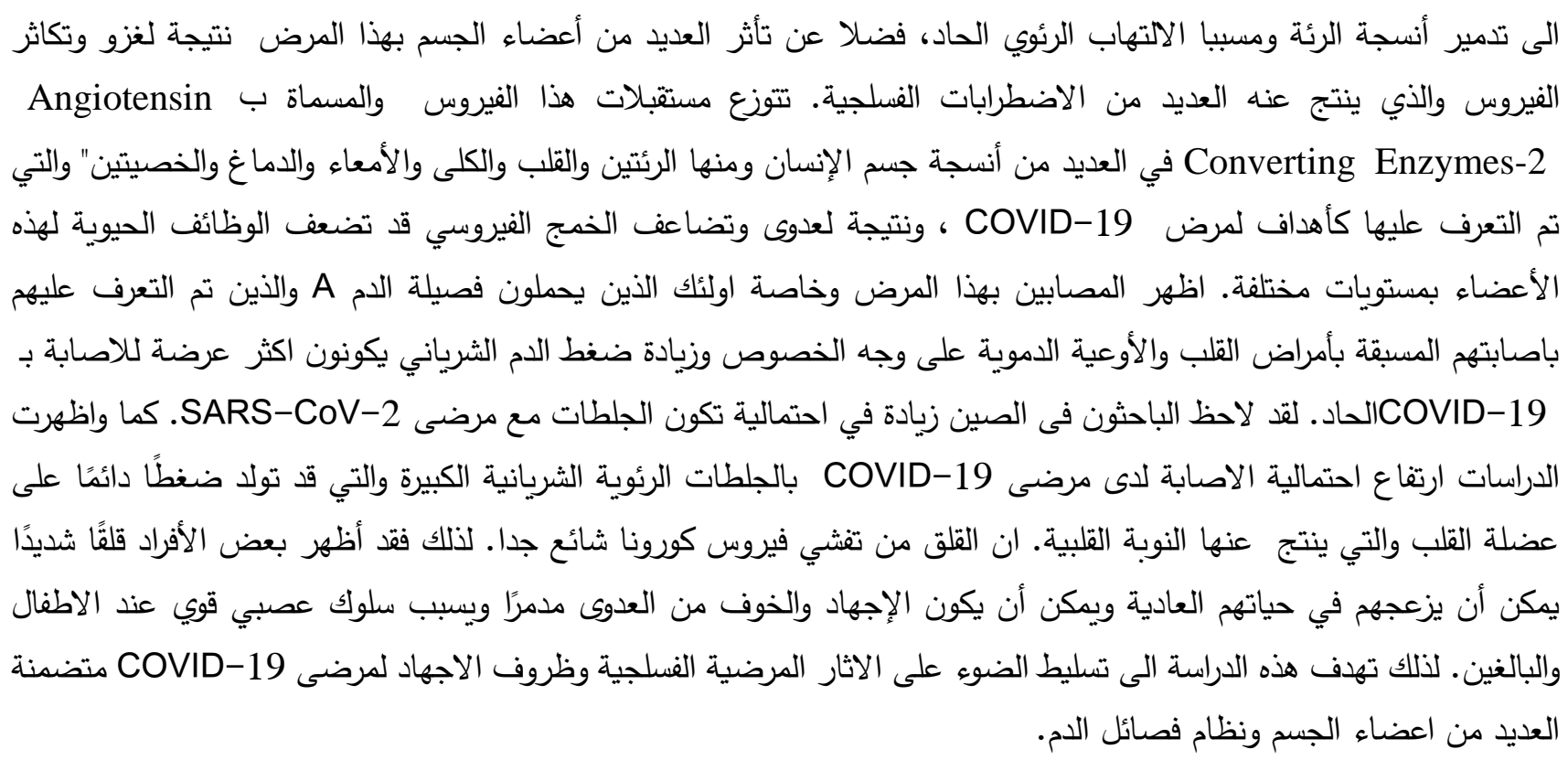

\section{Introduction}

An emergence of sudden and acute respiratory symptoms outbreak started in Wuhan City (China) in 31 Dec / 2019 and later called "Corona Virus Disease (COVID19)". The characteristic clinical symptoms of the infected patients include fever, pneumonia cough and tiredness (1). This disease is characterized by highly infectious and transmissible rate between populations after being quickly spread to human community and country (2).

Many of respiratory viruses impaired immune responses to give a chance for effective virus replication and development of the infection that may cause tissue destruction (3). Through viral infection the architecture of lung tissue is commonly compromised mainly by the immune system of the host. Coronaviruses mainly infect the alveoli, and therefore are more likely to destroy lung tissue and cause pneumonia during illness. Therefore damage of tight junctions, increase vascular permeability, edematous and fibrinous exudate buildup in the alveoli can lead to necrosis of alveolar tissue and decrease of surfactant will imitate the alveolar collapse (4).

A recent study reports that severe respiratory failure in patients occurs as a result of neurotropic potential of the COVID-19 when the virus exists in the cerebrospinal fluid (5).

\section{Physiological consequences of SARS CoV-2}

The proceeding COVID-19 pandemic is induced by new coronavirus CoV. Obesity, smoking, age, and chronic diseases have been expressed as hazard aspects for serious problems and death with COVID-19 (6). Diabetes and obesity are commonly accompanied with irregular lipid creation and clearance which can establish or exacerbate inflammation and damage of lung tissue (6). When the virus invades the target cell tend to use the cellular organelles of the individual to replicate and produce a new viral progeny to cause of viral infection and then subsequently shed from infected host cell. Therefore many organs of COVID 19 patients are affect by these Pathophysiological consequences which include: 


\section{Cardiac effects}

Various studies observed that the COVID 19 virus binds to ACE2 receptors to invade the host's cells $(7,8)$. People with cardiovascular disorder are more susceptible to coronavirus infection (9). Physiologically, the functions of each of the smooth vascular muscle cells lining the arteries within the glomeruli, renal tubular epithelium, heart, lung, brain and intestine depends on the protein enzyme called renin-angiotensin-aldosterone system (RAS) (10). (Figure 1)

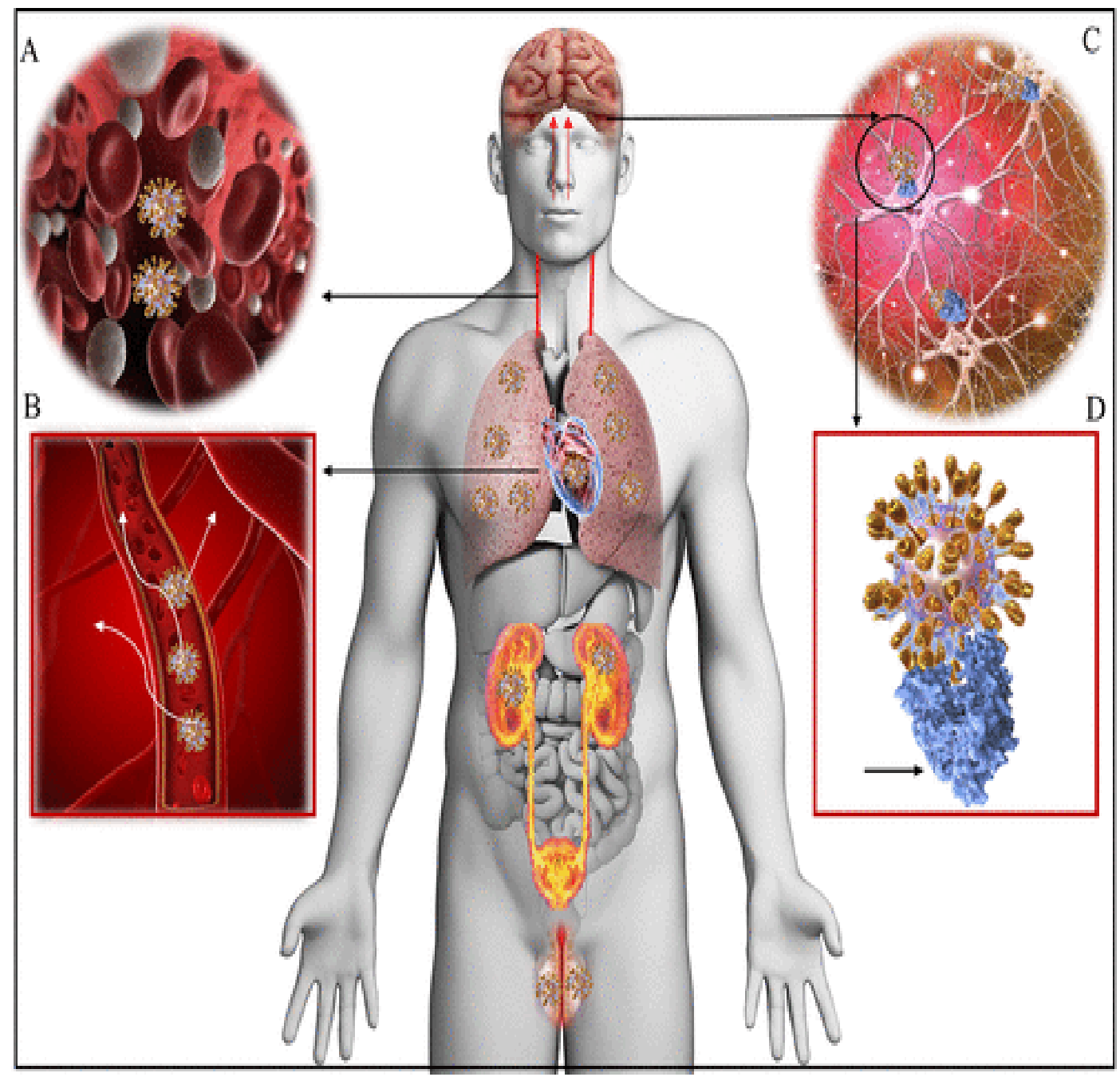

Figure (1):- Illustrate the location of angiotensin converting enzyme 2 (ACE2) receptors in human's tissues "lungs, heart, kidneys, intestines, brain and testes" that are recognized as a possible targets of COVID-19 (3)

ANG II is a peptide structure that increases markedly from ACE2 degradation by the virus, this peptide has a multiple functions by controlling the incidence of the Cardiovascular disease (CVD) and produce ANG (1-7) which have antagonist action to ANG II (11). The primary function of ACE2 in the heart is to formation of ANG (1-7) as a result of ANG II metabolism. The loss of enzyme (carboxypeptidase) will affect the heart functions regardless of viral infection $(12,13)$ (Figure 2). 


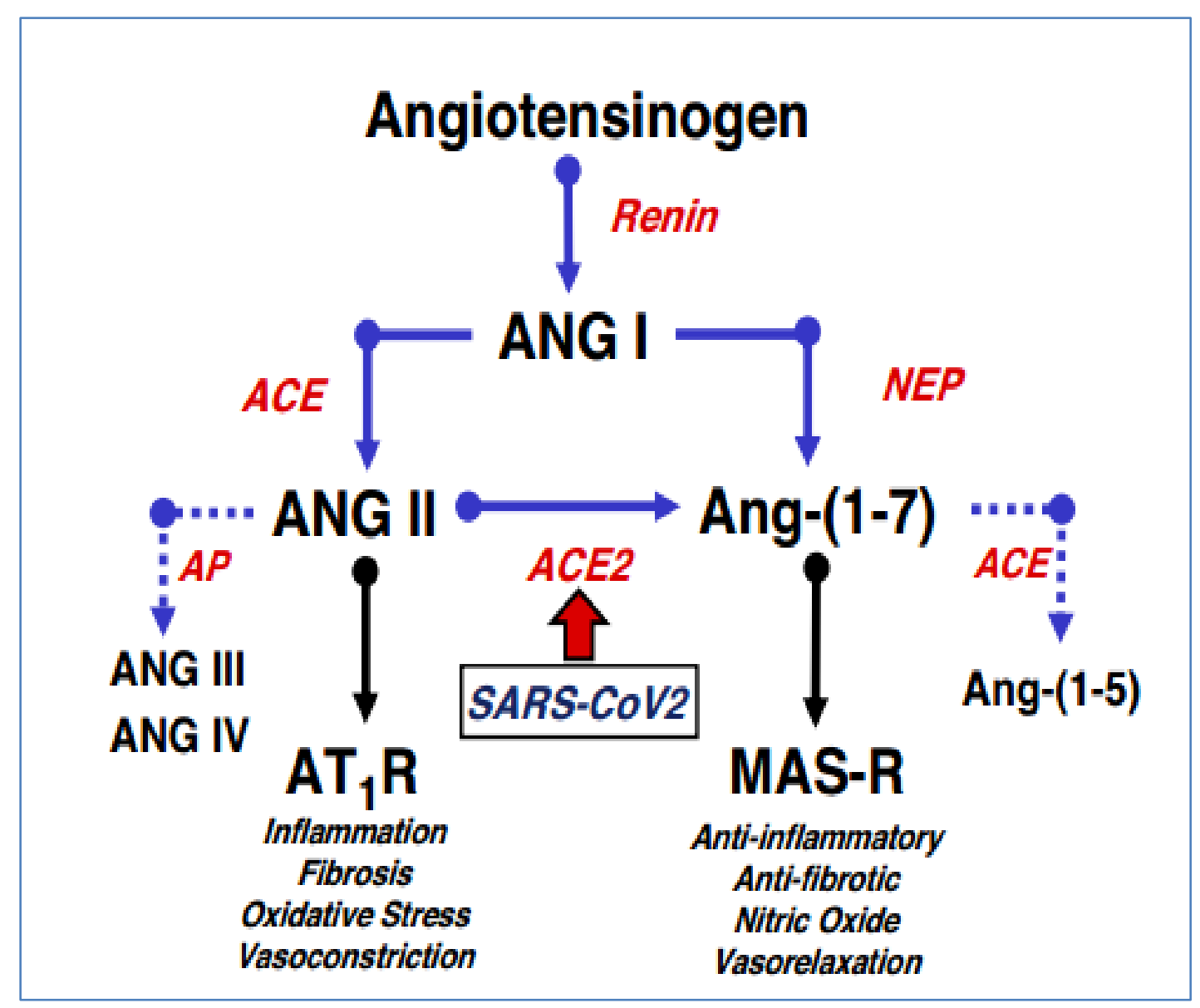

Figure (2):-Role of the renin-angiotensin system (RAS) in the formation of Angiotensin II (9)

\section{Kidney}

ACE2 receptors are found and distributed extensively in the tubular epithelium of the kidneys and contribute effectively to the transportation of sodium in the renal tubules. Therefore, the loss of ACE2 leads to increased blood volume and pressure in addition to its acute and chronic effects on renal injury $(14,15)$.

\section{Brian}

The vital function of nervous cells in the brain can be disrupted by some of viral infections (16). In addition, loss of ACE2 in the cardiovascular and brain centers as a result of neuronal cell death can lead to a loss of control function of the autonomic nervous system which regulates breathing action and blood pressure (17).

\section{Lung}

Exacerbation of blood pressure can occur as a result of changes in the baroreflex receptors thus will lead to an increase of sympathetic flow $(18,19)$. The loss of ACE2 in the lining of the blood vessels can lead to inflammation in the lining of the vasculature, moreover to the aggravation of diabetes and atherosclerosis (20,21). Wastage of pulmonary ACE2 may aggravate the increasing of blood pressure, disturbance in respiratory system, thickening and scarring of connective tissue after viral infection (22). 


\section{Gastrointestinal tract}

People with COVID-19 infection showed abnormalities in the respiratory system and increased body temperatures. Furthermore it may appear on some people signs of abdominal pain, diarrhea and vomiting (23). Many studies have specified the COVID-19 RNA in rectal swabs $(24,25)$ and stool samples $(26,27)$ of COVID-19 of people, still after the deliverance of the virus from upper respiratory tract $(26,27)$. Moreover, the ACE2 were found to be expressed in the lining of stomach and intestine $(28,29)$. Simultaneously these proposed that SARS-CoV-2 can vigorously participate in the infection and replication in the alimentary tract. So this has serious embodiment to the disease transmission, handling, and restriction of infection (30).

Presently, directory appears that COVID-19 needs ACE2 to invade the target cell (31). Alongside the transmembrane serine protease (TMPRSS2) is considered as a principle steward cell protease which splits the $\mathrm{S}$ protein of human SARS-CoV on the cell membrane receptors, giving the opportunity to the viral attachment with cell membrane receptors $(32,33)$ (Figure 3). In the alimentary tract, the epithelial cells of esophagus, co representation of ACE2 and TMPRSS2 that also expands in the enterocytes from the lower gastrointestinal tract which are the most susceptible cells of epithelium (34). The barrier function of intestinal epithelial cells during microbial infection can help the assortment immune system (35). Disruption of enterocytes absorptive function can also occur in COVID-19 patients, resulting to diarrhea due to mal-absorption, destruction, Imbalance of alimentary tract secretion and enteric nervous disorders $(36,37)$.

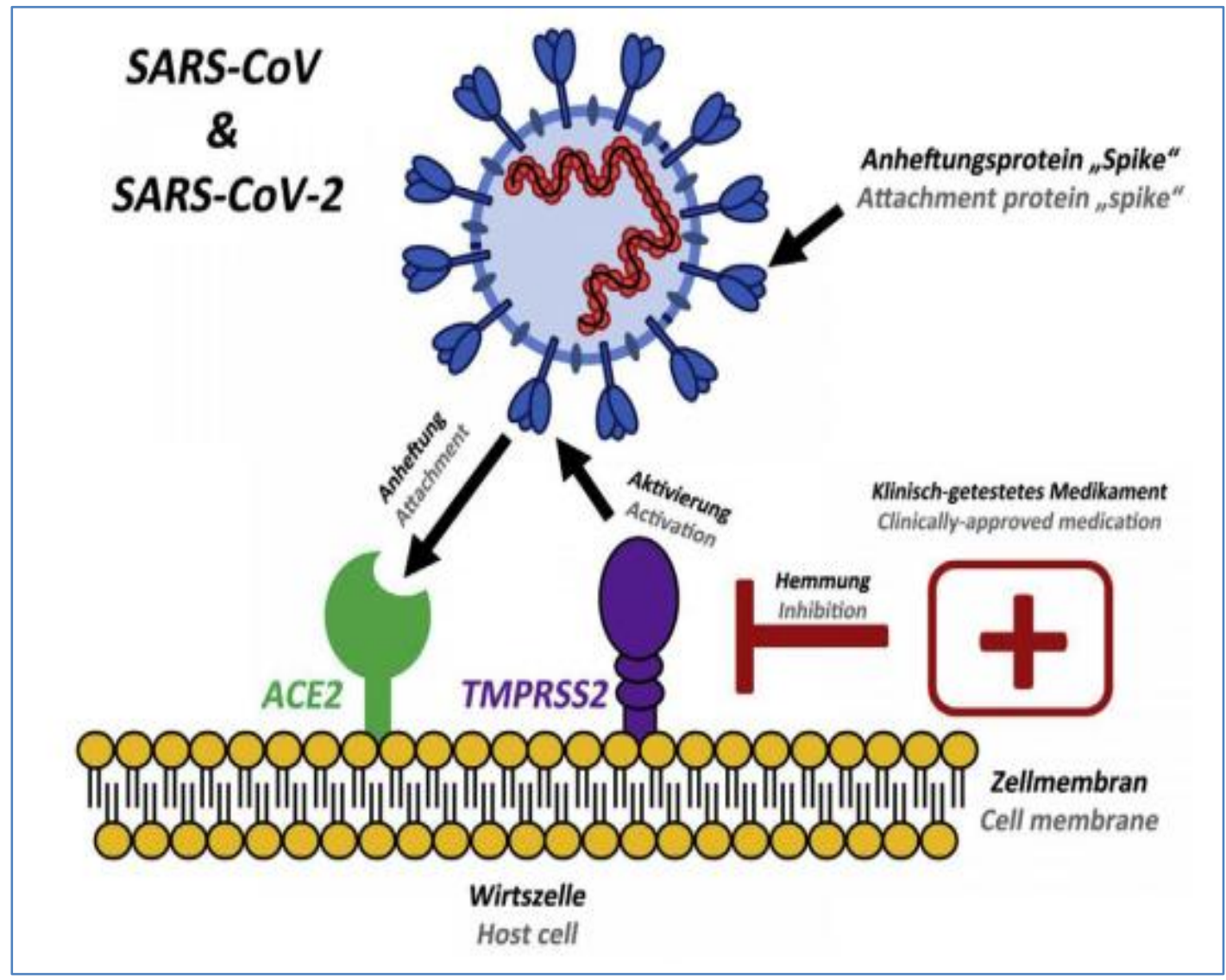

Figure (3):- Attachment of SARS-COV-2 spike on to ACE2 receptors of susceptible cell (34) 


\section{Liver injury}

With the exception of symptoms of the digestive system, people who suffer from COVID-19 can also show a liver injury with an increase in the levels of enzymes present in blood stream. Where's another recent study indicate that $14.8-53.1 \%$ of COVID-19 patients have unusual values of alanine aminotransferase (ALT) and aspartate aminotransferase (AST), with particularly high value in serum bilirubin. Damage of liver might occur because of immune-related condition $(38,39)$, viral invasion of hepatocytes, or hepatotoxic medication (40). There is also proposition that the SARS-CoV-2 may bind to cholangiocytes through the ACE2 receptors to disturb the liver functions (41). Biopsy from COVID-19 patients for histological examination of the liver indicates mild lobular activity and microvesicular steatosis (42).

\section{ABO system and its relation to COVID -19}

The ABO system is a vital indicator for priming of COVID-19, as the ABO group shows different relationships for the risk of COVID-19, especially blood group A that has to do with an increased risk of developing the disease unlike group $\mathrm{O}$ (43). Anti A antibodies (Abs) specifically suppress the cleavage of viral S protein to bind with ACE2 expressing in cell lines (44) Given the receptor (ACE2) binding similarity $(45,46)$. Higher sensitivity of type $A$ in compare with lower sensitivity of type $\mathrm{O}$ for COVID-19 may be related to the to the existence of normal predominant anti-A Abs in the blood stream (43).

Many studies notify that the ABO system is correlated with ACE activation / inhibition-induced to cough in Chinese patients associated with hypertension $(47,48)$ furthermore, the blood group A patients show the GATC (Guanine, Adenine, Thymine, Cytosine) haplotype polymorphisms for genes of ABO system (rs8176746, rs8176740, rs495828, rs12683493) which is definitely associated with ACE activity (48). In this way patients with type $\mathrm{O}$ must have a lesser ACE receptors and a superior possibility of enjoying protection from ACE2-expressed values. Therefore, people with type $\mathrm{O}$ have a crucial role in maintaining the ACE2 level and controlling a steady level of RAS and thus reducing the risk of high blood pressure (49). Thus patients with type A, particularly those previously have been diagnosed with cardiovascular disorder in particular increase blood pressure, are more expected to develop acute COVID-19 once infected in the contrary with patients having type $\mathrm{O}$ are less likely to arise cardiovascular disorder (CVD) and acute COVID-19 (Figure 4).

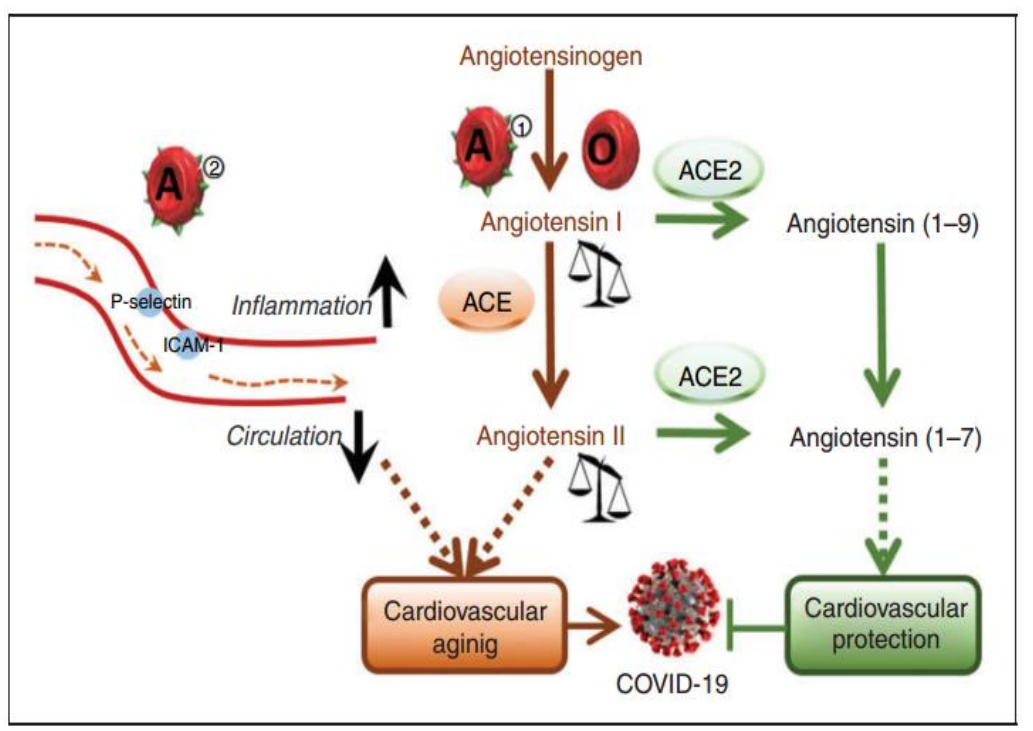

Figure (4):- Relationship between ABO blood group and ACE2 receptors (50) 


\section{Clot disorders in COVID 19 patients:}

There is an event risk occuers at the lung infected with COVID-19 that may cause sudden, occasionally fatal impairment as a result of blood clots (51). Clot forming disorders in SARS CoV-2 patients were noticed firstly by researchers in China in February. Untreated patients suffered from large arterial lung clots can put irreversible pressure on the heart, leading to cardiac arrest (51). Even very small clots in the blood vessels of lung may interfere with blood flow, declining many attempts to help patients with ventilators. Researchers establish close relationship between thrombus and inflammation (52). And therefore this evidence demonstrates that COVID-19 is correlated to the typical syndrome called disseminated intravascular coagulation (DIC). Doctors of the ICU often assign the clinical remarks of COVID-19 patients that are hyperactive coagulable, and the incidence of pulmonary embolus is possibly superior in these patients. Furthermore, when heparin was used in COVID-19 patient it shows beside its anticoagulant role, some immunomodulatory and anti-inflammatory features (53).

\section{Stress in COVID-19 patients}

Many people exhibit signs from anxiety during a pandemic COVID-19. This is through feeling about quarantine, economic and death anxiety. Of course, feeling the stress now is predictable, but the reduction of its effects on our views and bodies. This type of stress and anxiety is restrained by a vital system called the endocrine system, when the absence of homeostasis occurs and arising disorders of endocrine system (54).

Numerous hormones are produced by endocrine glands that send significant signals through the blood stream and from there to the target organs for control breathing activity, water balance, blood pressure, metabolic function, etc. Cortisol is considered as one of the most important hormones that is delivered as a reply to stress (55)

Cortisol is created in the zona faciculata cells of adrenal glands under the influence of adenocorticotropic hormone $(\mathrm{ACTH})$ from pituitary and corticotropen releasing hormone $(\mathrm{CRH})$ from hypothalamus .Cortisol is one of the steroidal hormones, as a result of its fat-soluble features can pass through the cytoplasmic membrane and then enters the cell for binding with particular receptors in the cytoplasm. While when cortisol is absent, the glucocorticoid receptors are bound to a protein accompanying Heat Shock protein 90 (Hsp90). The binding of cortisol with the glucocorticoid receptors separate Hsp90. Thus the complex of cortisol-receptor enters the cell nucleus and affects the transcription of cortisol gene (56,57). Cortisol is released during stress exposure as a result to regulate and respond to this pressure, but when the amount of cortisol in the blood increases; on the other hand, it is the problematic. There is no doubt that we are all exposed to some level of stress, as we observe that the COVID-19 obliges us to make some major changes in our daily lives. This stress response is potent for people who have been genetically shocked or weak to hypertension.

The SARS virus uses one of the primary immune response to abolish the cortisol response. To complete this, there are some SARS-CoV amino acids sequences that perform as a molecular recreation of adrenocorticotropic hormone $(\mathrm{ACTH})$. The former 24 amino acids of ATCH (ACTH124) are largely preserved while ACTH 25-39 amino acids represent the less conserved region. The particular amino acids in location 26, 29, 31, 33, 37, and 39 have an essential site as an ACTH antigen. SARS and virus of influenza have a numerous replacement sequences of the amino acid with the homogenization of these capacity major ACTH residues. In contrast, another study hypothesizes the antibodies that are created by the B-cells of individual to offset the virus, in order, will abolish the individual ACTH unwittingly, limiting the elevation of cortisol. This means that all SARS patients may have a relative cortisol deficiency (58). 
The amygdala is the portion of the brain that is influenced by fear. A Magnetic resonance imaging (MRI) study, which measures blood flow to specific areas of the brain, finds that there is an increase in stimulation of the amygdala when participants experience stress (58) Also, when the cells exposed to a stressful situation lead to produce Heat shock proteins (HSPs) in addition to stress hormone. (HSPs) are produced under some physiological circumstances as results of different types of stimuli involving chemical, microbial and physical stimuli. These types of proteins are recognized as protective particles to cells from different models of stress involving extreme temperature. The physiological mechanism of HSPs is by regulation the of-cellular signaling paths. HSPs act as molecular chaperones and show critical activities in case of viral cell attachment, viral replication, gene expression, viral protein folding, assembly of virus particles and apoptotic mechanism (59).

\section{Conclusions:}

As a result of virus invasion to many organs, patients with COVID show numerous Pathophysiological consequences. The presence of angiotensin converting enzyme 2 (ACE2) receptors in different human's tissues are established as a potential targets of COVID-19. Infection of pulmonary tissue with COVID-19 may cause sudden and/or serious injury due to blood clots and stress development in COVID-19 patients is highly is predictable.

\section{References:}

1- Huang C, Wang Y, Li X, Ren L, Zhao J, Hu Y, Zhang L, Fan G, Xu J, Gu X, Cheng Z, Yu T, Xia J, Wei Y, Wu W, Xie X, Yin W, Li H, Liu M, Xiao Y, Gao H, Guo L, Xie J, Wang G, Jiang R, Gao Z, Jin Q, Wang J, Cao B. Lancet 395, 497-506.(2020)

2- Casadevall A , Pirofski L. Clinical Investigation( 2020)

3- Baig AM, Khaleeq A, Ali U, Syeda H. ACS Chem. Neurosci. 11, 995-998.(2020)

4- Newton AH , Cardani A, Thomas J. Braciale1. Semin Immunopathol . 38:471-482. (2016)

5- Mao L, Wang M, Chen S, He Q, Chang J, Hong C, Zhou Y, Wang D, Li Y, Jin H, Hu B. JAMA Neurol. (2020)

6- Saba H, Mahmood H, Abiola S, Ahmad A, Rifat H, Alawi A, Qutayba H (2020)

7- Hoffmann M, Kleine-Wever H, Kruger N, Muller M, Drotsten C, Pholhlmann S. Cell 181: 1-10 (2020)

8- Wrapp D, Wang N, Corbett KS, Goldsmith JA, Hsieh CL, Abiona O, Graham BS, McLellan JS. Science 367: 1260-1263 (2020)

9- South AM, Diz DI, Chappell MC. Am J Physiol Heart Circ Physiol 318: H1084-H1090. First published March 31 ( 2020)

10- Oudit GY, Imai Y, Kuba K, Scholey JW, Penninger JM. official publication of the European Dialysis and Transplant Association - European Renal Association. 24 (5):1362-5 (2009)

11- Garabelli PJ , Modrall JG , Penninger JM . Exp Physiol , 9 :.613-621,2008.

12- Santos RAS, Oudit GY, Verano-Braga T, Canta G, Steckelings UM,Bader M. Am J Physiol Heart Circ Physiol 316: H958H970 (2019))

13- Simões E Silva AC, Teixeira MM. Pharmacol Res 107: 154-162 (2016)

14- Williams VR, Scholey JW. Curr Opin Nephrol Hypertens 27: 35-41 (2018)

15- Chappell MC, Marshall AC, Alzayadneh EM, Shaltout HA, Diz DI. Front Endocrinol (Lausanne) 4: 201-215 (2014))

16- Li YC, Bai WZ, Hashikawa T. J Med Virol 2020

17- Wrapp D, Wang N, Corbett KS, Goldsmith JA, Hsieh CL, Abiona O, Graham BS, McLellan JS. Science 367: 1260-1263 (2020) 
18- Xu P, Sriramula S, Lazartigues E. Am J Physiol Regul Integr Comp Physiol 300: R804-R817 (2011)

19- Alenina N, Bader M. Neurochem Res 44: 1323-1329 (2019)

20- Sahara M, Ikutomi M, Morita T, Minami Y, Nakajima T, Hirata Y, Nagai R, Sata M. Cardiovasc Res 101: 236-246 (2014)

21- Tikoo K, Patel G, Kumar S, Karpe PA, Sanghavi M, Malek V, Srinivasan K. Biochem Pharmacol 93: 343-351 (2015)

22- Sodhi CP, Wohlford-Lenane C, Yamaguchi Y, Prindle T, Fulton WB,Wang S, McCray PB Jr, Chappell M, Hackam DJ, Jia H. Am J Physiol Lung Cell Mol Physiol 314: L17-L31 ( 2018)

23- Gu J, Han B, Wang J. Gastroenterology (2020)

24- Zhang W, Du RH, Li B et al. Emerg. Microbes. Infect. 9:386-389 (2020) doi.org/10.1038/s41591-020-0817-

25- Xu Y, Li X, Zhu B et al. Nat. Med (2020)

26- Holshue ML, DeBolt C, Lindquist S et al. N. Engl. J. Med. 382: 929-936. (2020)

27- Young BE, Ong SWX, Kalimuddin S et al. JAMA (2020)

28- Xiao F, Tang M, Zheng X, Liu Y, Li X, Shan H. Gastroenterology (2020)

29- Harmer D, Gilbert M, Borman R, Clark KL. FEBS Lett. 532: 107- 110. (2002)

30- Sunny H Wong, Rashid NS Lui ,Joseph JY Sung. Journal of Gastroenterology and Hepatology (2020)

31- Zhou P, Yang X-1, Wang X-g. Nature .579:270-3 (2020)

32- Gallagher TM, Buchmeier MJ. Virology , 279:371-4 (2001)

33- Hoffmann M, Kleine-Weber h, schroeder s, et al. Cell (2020)

34- Hao Zhang,Zijian Kang, haiyi gong, Da Xu, Jing Wang, Zhixiu li, Zifu li, Xinggang cui, Jianru Xiao, Jian Zhan, Tong Meng, Wang Zhou, Jianmin liu, huji Xu. Gut immunity (2020)

35- Haber al, Biton M, Rogel N. Nature .551:333-9 (2017)

36- Crawford SE, Ramani S, Tate JE, Parashar UD, Svensson L, Hagbom M, Franco MA, Greenberg HB, O'Ryan M, Kang G, Desselberger U, Estes MK . Nat Rev Dis Primers (2017)

37- Desmarets MB, Theuns S, Ioukaerts DMl. J Gen Virol ,95:1911-8 (2014)

38- Shi H, Han X, Jiang N et al. Lancet Infect. Dis (2020)

39- Yang X, Yu Y, Xu J et al. Lancet Respir. Med (2020)

40- Xu L, Liu J, Lu M, Yang D, Zheng X. Liver Int. (2020)

41- Zhang C, Shi L, Wang FS. Lancet Gastroenterol. Hepatol. (2020)

42- Xu Z, Shi L, Wang Y et al. Lancet Respir. Med. (2020)

43- Jiao Zhao, Yan Yang, Hanping Huang, Dong Li , Dongfeng Gu1, Xiangfeng Lu , Zheng Zhang, Lei Liu, Ting Liu, Yukun Liu, Yunjiao He1, Bin Sun, Meilan Wei1, Guangyu Yang, Xinghuan Wang8, Li Zhang, Xiaoyang Zhou, Mingzhao Xing1, Peng George Wang .MedRxe (2020)

44- Guillon P, Clément M, Sébille V, Rivain JG, Chou CF, Ruvoën-Clouet N, Le Pendu J. Glycobiology. 18(12):1085-93 (2008)

45- Li W, Moore MJ, Vasilieva N, Sui J, Wong SK, Berne MA, Somasundaran M, Sullivan JL, Luzuriaga K, Greenough TC, Choe H, Farzan M. J Nature. 27;426(6965):450-4 (2003)

46- Wan Y, Shang J, Graham R, Baric RS, Li F. J. Virol. JVI.00127-20 (2020)

47- Lu R, Zhao X, Li J, Niu P, Yang B, Wu H, Wang W, Song H, Huang B, Zhu N, Bi Y, Ma X, Zhan F, Wang L, Hu T, Zhou H, Hu Z, Zhou W, Zhao L, Chen J, Meng Y, Wang J, Lin Y, Yuan J, Xie 
Z, Ma J, Liu WJ, Wang D, Xu W, Holmes EC, Gao GF, Wu G, Chen W, Shi W, Tan W. Lancet. $30(2020)$

48- Luo JQ, He FZ, Luo ZY. Pharmacogenet Genom .24: 306-313 (2014)

49- Gasso P, Ritter MA, Mas S, et al. J Renin Angiotensin Aldosterone Syst , 15: 580-584 (2014)

50- Xiaofeng Dai. ESC (2020)

51- (ikdeli B, Madhavan MV, Jimenez D, Chuich T, Dreyfus I, Driggin E, Nigoghossian C, Ageno W, Madjid M, YutaoGuo Y, LiangV Tang, Hu Y, Giri J, Cushman M, Quéré I, Evangelos P,. Gibso M, Lippi G, Gregory L. Journal of the American College of Cardiology (2020)

52- Iba T, Levy JH. J Thromb Haemost , 16: 231-41 (2018)

53- Li X, Ma X. Br J Haematol. 179: 389-98 (2017)

54- Ranabir S, Reetu K..Indian. J. Endocrinol. Metab. 15(1): 18-22 (2011)

55- Hakamata Y, Komi S, Moriguchi Y, Izawa S, Motomura Y, Sato E, Mizukami S, Kim Y, Hanakawa T, Inoue Y, Tagaya H. Sci. Rep. 16; 7(1):8313 (2017)

56- Lee DY, Kim E, Choi MH. BMB Rep. 48(4):209-16 (2015)

57- Wheatland R. Med. Hypoth. 63:855-862 (2004)

58- Balderston NL, Schultz DH, Baillet S, Helmstetter FJ. PLoS One [Internet]. 9(5):e96803 (2014)

59- Azam Bolhassani P, Agi E. Clinica Chimica Acta . 498: 90-100 (2019) 